Jerzy Duda

UKSW, Warszawa

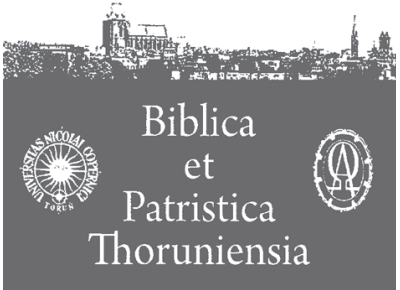

4 (2011) ISSN 1689-5150

\title{
Rajskie „drzewo poznania dobra i zła” w literaturze wczesnochrześcijańskiej
}

\section{"The tree of knowledge of good and evil" of early christian literature}

Słowa kluczowe: raj, drzewo poznania dobra i zła, grzech. Księga Rodzaju.

Key words: paradise, the tree of knowledge of good and evil, sin, Genesis.

B iblijna historia upadku w raju Adama i Ewy należy do najbardziej intrygujących w dziejach rozwoju teologii. Na przestrzeni wieków zarówno w Kościele katolickim, jak też w środowiskach heterodoksyjnych próbowano doszukać się w niej odpowiedzi na fundamentalne pytania dotyczące człowieka, jego powstania, sensu istnienia, samoświadomości, powołania, miejsca w świecie, kondycji moralnej, skłonności do dobra czy też zła, kosmologii itd. Początkowe rozdziały Księgi Genesis stały się kanwą rozważań całej historii zbawienia i konsekwentnie wyartykułowanego z czasem Credo Kościoła z jego fundamentalnymi dogmatami dotyczącymi odkupienia, zbawienia, kreacjonizmu, demonologii, czy też grzechu pierworodnego. Nie dziwi więc fakt, że na podstawie pierwszych trzech rozdziałów z Księgi Rodzaju powstała z czasem ogromna literatura przedmiotu zdecydowanie wykraczająca poza granice teologii. Współczesne szczegółowe badania filologiczne, archeologiczne, historyczne oraz biblijne dowodzą, iż prosta fabuła tych opowiadań kryje w sobie treść, której do dzisiaj nie jesteśmy w stanie jednoznacznie zinterpretować, czy też dogłębnie odczytać w duchu myśli piszącego przed wiekami autora natchnionego ${ }^{1}$. Wśród wielu interesujących fragmentów perykopy dotyczącej upadku pierw-

1 Por. C. Schedl, Historia Starego Testamentu. Starożytny Wschód i prehistoria biblijna, t. 1, tłum. S. Stańczyk, Tuchów 1995, s. 254-260; E. Zawiszewski, Pięcioksiąg. Księgi historyczne, Pelplin 1996, s. 7-17; M. Grabowski, Historia upadku. Ku antropologii adekwat- 
szych rodziców z Księgi Genesis na szczególną uwagę zasługuje tekst o rosnącym, w zasadzonym przez Boga ogrodzie Eden, drzewie poznania dobra i zła ${ }^{2}$. Zerwanie z tego drzewa przez Ewę owocu stało się początkiem tragedii upadku człowieka w grzech ${ }^{3}$. Czytających Biblię niemalże w każdej epoce frapowało pytanie o znaczenie tego symbolicznego drzewa oraz o zakazany owoc. Do dnia dzisiejszego kwestia ta nie doczekała się jasnego wytłumaczenia ${ }^{4}$. Dlatego też

nej, Kraków 2006, s. 116-157; Z. Ziółkowski, Najtrudniejsze stronice Biblii, Warszawa 1997, s. 151.

2 Por. Rdz 2, 8-9.

3 Por. tamże, 3, 1-24. Zob. E. Testa, Il Peccato di Adamo nella Patristica, Hierosolymis 1970, s. 147-192.

4 Współcześnie kontrowersje biblijne budzi nawet sam fakt istnienia drzewa poznania dobra i zła. Schedl zauważa, iż mając na uwadze czysto formalne kryteria starohebrajskiej poezji, to opis umieszczenia przez Boga w środku ogrodu drzewa życia, należałoby odnieść do drzewa poznania dobra i zła, gdyż chodzi o ten sam podmiot. Według niego jest to jedynie poetycki paralelizm, zaś słowa „drzewo życia” i „drzewo poznania dobra i zła” to jedynie powtórzenie i dookreślenie tego samego rzeczownika. Jako dowód podaje kluczową zasadę egzegezy biblijnej, która wykorzystuje cały kontekst wypowiedzi. Poznanie (termin hebr. jada) ma odniesienie do sfery życia i jego przekazywania („Adam poznał żonę swą Ewę, a ona poczęła i zrodziła Kaina”. Rdz 4, 1). Zatem można wnioskować o tożsamości drzewa życia i poznania. Por. C. Schedl, dz. cyt., s. 249-250. Jednakże w większości specjalistycznych komentarzy istnieje zdecydowane rozróżnienie tych dwóch drzew, wraz z przypisaną do nich specyficzną wartością semantyczną. Zob. J. Soggin, Philological-Linguistic Notes on the Second Charter of Genesis, w: Old Testament and Oriental Studies, Biblica et Orientalia 29, Rome 1975, s. 171-172; M. Jacniacka, J. Szlaga, Drzewo życia, w: EK t. 4, kk 254-255; J. Synowiec, Początki świata i ludzkości wedtug Księgi Rodzaju, Kraków 2001, s. 99-110; Cz. Jakubiec, Genesis. Księga Rodzaju, Warszawa 1957, s. 52; J. Szlaga, Drzewo poznania dobra i zła, w: EK t. 4, kk 251-252. Chrostowski w sposób następujący streszcza najnowsze wyniki badań: „W wyniku dotychczasowych dyskusji coraz bardziej krystalizuje się pogląd upatrujący w tym drzewie aluzję do napięcia, jakie istnieje między możliwością podejmowania rozstrzygnięć i decyzji o tym, co słuszne, właściwe i sprzyjające życiu, a co nie, czy to wyłącznie na podstawie własnego rozeznania i doświadczenia czy też na podstawie absolutnych nakazów religii. W grę wchodzi zatem autonomia moralna człowieka, który przejmuje na siebie zadania i odpowiedzialność samodzielnego określenia - niezależnie od Boga - tego, co jest dla niego dobre albo nie. [...] Dotychczasowe objaśnienia natury drzewa znajomości dobra $i$ zła szły w trzech kierunkach. Jedna grupa uczonych upatrywała w nim środka do osiągnięcia pewnych specyficznie ludzkich właściwości, takich jak wartości moralne (K. Budde), czy moralna dojrzałość (H. Gunkel, U. Cassuto), prawo do samostanowienia (E. Speiser, A. Clamer, R. de Vaux) lub odpowiedzialność za podejmowane decyzje (W. M. Clark). Druga grupa (J. Coppens, L. Hartman, I. Engnell, R. Gordis, Cz. Jakubiec), zwracając uwagę na występujące $\mathrm{w}$ opowiadaniu pojęcia $\mathrm{z}$ podtekstem seksualnym [...], widziała w przymiotach drzewa nawiązanie do płciowości i wprowadzenia pierwszej pary ludzkiej w sferę doznań seksualnych. Trzecia grupa egzegetów (J. Wellhausen, P. Humbert, 
w niniejszym opracowaniu podejmiemy próbę przedstawienia nauki o drzewie poznania dobra i zła, na podstawie wybranych dzieł pisarzy wczesnochrześcijańskich.

Tematyka rajska wraz z komentarzami do perykopy biblijnej dotyczącej drzewa poznania dobra i zła pojawiła się już w najstarszych znanych nam pismach Ojców Apostolskich. W niewielkim utworze Epistula ad Diognetum określanym niekiedy „perłą literatury patrystycznej” ${ }^{2}$, tajemniczy anonimowy autor, nazywający siebie „uczniem Apostołów” i "nauczycielem narodów”, w apologetycznym uniesieniu stworzył analogię między ludźmi, którzy otwierają się na poznanie Bożych tajemnic i miłują swego Stwórcę, żyjąc w świętości, a rajskim ogrodem ${ }^{7}$. W takim kontekście pojawił się jeden $\mathrm{z}$ najstarszych w chrześcijaństwie komentarzy biblijnych dotyczących tematyki drzewa poznania dobra i zła. Mimo, że Pismo św. werbalnie nie określa, gdzie dokładnie rosło w raju drzewo wiedzy, to jednak autor tego dziełka uważa, że zostało ono posadzone obok drzewa życia, w środku ogrodu ${ }^{8}$. Było to uczynione przez Boga specjalnie, gdyż poznanie prowadzi do prawdziwego życia, jak również nie ma pełnego życia bez udzielonej przez Boga łaski poznania. Jest to dość oryginalna na gruncie teologii patrystycznej interpretacja. Autor utworu Do Diogneta uważa, że dążenie człowieka do zdobycia poznania nie jest przekleństwem, lecz drogą prowadzącą do życia. Dlatego też stwierdził, że to nie drzewo poznania przyniosło ludziom śmierć, lecz zabija nieposłuszeństwo. Problem pierwszych ludzi polegał na tym, że dali się zwieść przez węża i źle wykorzystali otrzymany przez Boga dar. Poznanie bowiem jest oparte na Słowie Prawdy i prawach życia $^{9}$. Inna wiedza, która lekceważy prawdę, wbija w pychę i konsekwentnie prowadzi do upadku i śmierci. Kto zaś szczerze kocha życie, szuka prawdy i wiedzę łączy z bojaźnią Bożą, doczeka się dobrych owoców. W takim przypadku historia człowieka będzie podobna do rajskiego ogrodu, a posadzone w nim drzewo

J. A. Soggin, H. N. Wallace) traktuje drzewo znajomości dobra i zła jako środek do zdobycia jakiejś odmiany wiedzy, która wykracza poza zwyczajne ludzkie możliwości i przysługuje wyłącznie Bogu”. W. Chrostowski, Ogród Eden - zapoznane świadectwo asyryjskiej diaspory, Warszawa 1996, s. 36. 38-39.

5 Por. M. Starowieyski, Do Diogneta - czyli o roli chrześcijan w świecie, w: Pierwsi świadkowie. Pisma Ojców Apostolskich, opr. M. Starowieyski, Kraków 1998, s. 334.

6 Epistula ad Diognetum XI, 1, SCh 33, 78, BOK 10, 346.

7 Por. tamże, XII, 1, SCh 33, 80, BOK 10, 347.

8 Por. tamże XII, 3, SCh 33, 82, BOK 10, 347.

9 Por. tamże, XII, 5, SCh 33, 82, BOK 10, 347. 
poznania i drzewo życia źródłem Bożych darów: świętości, zrozumienia, radości i zbawienia ${ }^{10}$.

Podobną myśl odnajdujemy w pochodzącym z II w. dziele Teofila z Antiochii pt.: Do Autolika. Biskup Antiochii w swojej apologii wspomina między wierszami o istniejącej w owym czasie kontrowersji dotyczącej drzewa poznania. Panowało bowiem wśród niektórych przekonanie, chodzi tutaj prawdopodobnie o stanowisko gnostyków ${ }^{11}$, iż w drzewie tym było coś złego, co w konsekwencji sprowadziło na ludzi śmierć ${ }^{12}$. Przeciwstawiając się takim poglądom, Teofil dowodził, iż drzewo poznania dobra i zła nie zawierało w sobie śmierci, lecz było dobre, podobnie jak dobre były jego owoce ${ }^{13}$. Do nich zaś zalicza się przede wszystkim poznanie, które samo z siebie, jeśli się go właściwie używa, jest dobre. Według Antiocheńczyka to nie zazdrość, jak sądzili niektórzy, kazała Bogu postawić Adamowi zakaz sięgania po owoce tego drzewa, lecz stan w którym człowiek się znajdował. Adam nie był jeszcze dojrzały i zdolny do tego, by właściwie skorzystać z daru poznania. Biskup Teofil mówi, iż w kwestii wieku, Adam był jeszcze młodzieńcem. Podobnie jak dziecko po swoim urodzeniu nie jest w stanie karmić się pokarmem stały, lecz jedynie mlekiem, tak również było $\mathrm{w}$ przypadku pierwszego człowieka. Wraz z upływem czasu Adam dojrzałby do głębszego poznania i odkryłby wiedzę odpowiednią do jego stanu $^{14}$. Na to jednak było jeszcze za wcześnie. To nie drzewo ani jego owoce sprowadziły na człowieka ból, cierpienie i śmierć, lecz grzech nieposłuszeństwa. Człowiek bowiem, jak dziecko ojcu, winien być Bogu poddany w całej swej prostocie, zaufaniu i niewinności. Drzewo poznania rosnące w Edenie i zakaz Boży zabraniający ludziom sięgać po jego owoce były sprawdzianem zaufania i posłuszeństwa ${ }^{15}$. Zatem według Teofila z Antiochii to złamanie Bożego prawa oraz nieposłuszeństwo stało się przyczyną wypędzenia pierwszych ludzi $z$ raju.

Biblijna historia ogrodu Eden oraz wydarzeń związanych z sięgnięciem przez człowieka po owoce $z$ drzewa poznania dobra i zła inspirowała nie tylko pisarzy chrześcijańskich, lecz znalazła swoje silne odzwierciedlenie w utworach gnostyków. Ci jednak, mimo że przedstawiali swoje poglądy wykorzystu-

10 Por. tamże, XII, 8, SCh 33, 82, BOK 10, 347-348.

11 Tematyka interpretacji drzewa poznania dobra i zła w środowisku gnostyckim zostanie podjęta $\mathrm{w}$ dalszej części niniejszego opracowania.

12 Por. Theophilus Antiochenus, Ad Autolycum II, 25, 8, SCh 20, 160-162, BOK 24, 423-424.

13 Por tamże, II, 25, 1, SCh 20, 160, BOK 24, 423.

14 Por. tamże, II, 25, 5, SCh 20, 160, BOK 24, 423.

15 Por. tamże, II, 25, 4, SCh 20, 160, BOK 24, 423. 
jąc całą gamę cytatów biblijnych, $\mathrm{z}$ historią ich bohaterów oraz wydarzeniami rozgrywającymi się na kartach Księgi Rodzaju, nadali im przede wszystkim alegoryczne, bądź mityczne znaczenie, zaś treść ich była często skrajnie różna od tradycyjnego przekazu Kościoła ${ }^{16}$. Gnostycy wykorzystali opowieść o drzewie poznania w stworzonych przez siebie mitach kosmologicznych, zaś samo drzewo gnozy, mając na uwadze nazwę i bezpośrednie odniesienie do wiedzy, zajęło u nich miejsce priorytetowe. W Apokryfie Jana, objawionym według gnostyckiej konwencji przez Pana Jezusa apostołowi Janowi, odnajdujemy dość ciekawą i klasyczną w obrębie tej grupy pism interpretację. Drzewo wiadomości zasadzone w ogrodzie, podobnie jak cały raj, pochodzi od Demiurga, twórcy materii i nie może być dobre. Człowiek stojący w centrum tej historii jest uwikłany w odwieczną walkę między rzeczywistością światła i ciemności, dobra i zła, ducha i materii. Sam jest zagubiony i oszukany przez archonta Jaldabaotha, który umieściwszy go w raju, starał się mu wmówić, iż jest to świat najlepszy z możliwych, pełen rozkoszy i szczęścia. Dzięki Jezusowi, który prawdopodobnie pod postacią węża zbliżył się do człowieka i namówił go do nieposłuszeństwa swemu Stwórcy, Adamowi otworzyły się oczy i poznał, kim są archonci oraz swoje miejsce w tej historii oraz powołanie do świata ducha. Rajskie drzewo życia, w kluczu gnostyckim, zasadzone przez archontów, jest złowrogie, zaś jego owoce niosą śmierć. Archontom zazdrosnym o pierwiastek duchowy, zależało, by oszukać człowieka i dać mu życie w świecie, w którym nie jest w stanie poznać swej doskonałości. Zatem skosztowanie owocu z drzewa wiedzy, jako nieposłuszeństwo Adama, było inicjacją gnozy i wejściem na drogę do zbawienia ${ }^{17}$. Wąż namawiający do sięgnięcia po owoce poznania, stał się często w koncepcjach gnostyckich ucieleśnieniem transcendentnej zasady „pneumatycznej”, źródłem mocy zbawczej, przeciwstawionej biblijnemu Stwórcy świata i materii ${ }^{18}$. Potwierdzenie tego typu przekazu odnajdujemy w innym gnostyckim utworze, pochodzącym z II kodeksu znalezionego w Nag Hammadi, pt. Hipostaza archontów. Według autora tego dzieła archonci przez zazdrość zabronili nie tylko jeść, ale też dotykać drzewa poznania dobra i zła. Adam jednak, okazując nieposłuszeństwo archontom, stał się im podobny, poznając nie tylko dobro i zło, ale również i to, że do tej pory był nagi, w znaczeniu uczestniczenia w świecie ducha ${ }^{19}$. Tego rodzaju poglądy powtarzają się

16 Por. W. Myszor, Nauka o grzechu w przekazach gnostyckich, w: Grzech pierworodny, Kraków 2003, s. 10-11.

17 Por. tamże, s. 12.

18 Por. H. Jonas, Religia gnozy, tłum. M. Klimowicz, Liszki 1994, s. 106-107.

19 Por. W. Myszor, Nauka o grzechu w przekazach gnostyckich, s. 11. 
głównie w utworach gnostyckich należących do pism setiańskich ${ }^{20}$. W teologii gnozy walentyniańskiej drzewo wiadomości symbolizuje bądź klasę ludzi określonych mianem psychików, bądź też psychiczną części duszy, dzięki której człowiek jest w stanie dokonać wyboru między dobrem a złem ${ }^{21}$.

Poglądy gnostyków spotkały się w Kościele katolickim z ostrą polemiką. $\mathrm{W}$ zdecydowanym duchu antygnostyckim odnajdujemy komentarz do rajskiego drzewa poznania wśród pism „gnostyka chrześcijańskiego”, jakim był Klemens Aleksandryjski (+ ok. 215) ${ }^{22}$. Należąc do „alegorycznej szkoły” w interpretacji Pisma św. nadał mu znaczenie symboliczne. Według niego, drzewo wiadomości dobra i zła oraz zakaz spożywania z niego owocu można odnieść do sfery współżycia seksualnego. Ma to swoje uzasadnienie w wartości semantycznej hebrajskiego rzeczownika odczasownikowego da'at - tłum. poznanie, wiedza, który w innych perykopach biblijnych występuje w znaczeniu pożycia seksualnego z kobietą (por. Rdz 4, 1.17; Sdz 11, 39; 1 Sm 1, 19) ${ }^{23}$. Według Klemensa grzech pierwszych rodziców mógł polegać na tym, że jako małżonkowie sięgnęli oni po owoce rozkoszy seksualnej, która im była zakazana ${ }^{24}$. Bóg bowiem nie zezwolił im jeszcze wstąpić w związek małżeński i cieszyć się jego rozkoszą. Ludzie jednak zgrzeszyli nieposłuszeństwem, sięgając po ów owoc przed wyznaczonym przez Stwórcę czasem. Klemens w swojej argumentacji nawiązuje do poglądów zarówno Marcjona, walentynian i innych gnostyków, którzy deprecjonowali małżeństwo oraz sferę aktywności seksualnej, przyrównując ją do sfery potrzeb należnych nie ludziom, lecz zwierzętom ${ }^{25}$. Polemiści Scholarchy z Aleksandrii nauczali, że to wąż zachęcił pierwszych rodziców, by podjęli małżeńskie pożycie seksualne, do tej pory związane jedynie ze światem zwierzęcym i przynależnym mu naturalnym instynktem rozrodczym. Klemens naucza, że drzewo poznania jest symbolem współżycia seksualnego między mężczyzną a kobietą, gdyż ono prowadzi do narodzin życia, które łączy się nierozerwalnie z gnozą. Sfera seksualności człowieka, podobnie jak owo drzewo

20 Por. tenże, Ewangelia Judasza - wprowadzenie, w: Ewangelia Judasza, Katowice 2006, s. 21-36.

21 Por. tenże, Nauka o grzechu w przekazach gnostyckich, s. 14-15.

22 Por. H. Pietras, Początki teologii Kościoła, Kraków 2000, s. 122-125.

23 Por. J. Synowiec, Początki świata i ludzkości według Księgi Rodzaju, Kraków 2001, s. $106-107$.

24 Por. Clemens Alex., Stromata III, 14, 94, PG 8, 1193-1195.

25 Według gnostyckiej Ewangelii Filipa Adam zjadł z drzewa poznania, które uczyniło z niego zwierzę. To w konsekwencji było odwróceniem się człowieka od prawdziwego kultu i świata duchowego, ku oddaniu czci stworzeniom (zwierzętom) oraz zatopieniu się w tę rzeczywistość. Zob. W. Myszor, Nauka o grzechu w przekazach gnostyckich, s. 16. Por. Clemens Alex., Stromata III, 17, 102, PG 8, 1205-1208. 
posadzone przez Boga w raju, może być wykorzystana bądź do dobra, bądź do upadku i grzechu ${ }^{26}$.

Podobnie jak Klemens również i inni przedstawiciele „aleksandryjskiej szkoły" egzegezy biblijnej szukali w przedstawieniu posadzonego przez Boga rajskiego drzewa wiadomości dobra i zła znaczenia alegorycznego. Orygenes (+ ok. 253) charakteryzując w De principiis stworzoną przez siebie metodologiczną koncepcję istnienia obok siebie wielu sensów znaczeniowych tekstu natchnionego odwołał się do obrazu drzewa poznania, by wyjaśnić, iż literalny opis wydarzeń z nim związanych jest jedynie metaforą służącą do przekazania tajemnicy ${ }^{27}$. Niestety, nie dotarł do naszych czasów pełny tekst stworzonego przez Adamantiosa dzieła pt.: Commentarius in Genesis, gdzie jak sam pisze w Contra Celsum dokonał szczegółowego opracowania interesującej nas problematyki ${ }^{28}$. Na podstawie innych zachowanych jego pism można jednak wydobyć pewne ciekawe elementy. Drzewo wiadomości dobra i zła nie miało charakteru materialnego, ani Bóg nie był ogrodnikiem ${ }^{29}$. Opis z Księgi Rodzaju sięga według Aleksandryjczyka do świata preegzystencji, samo zaś drzewo poznania może oznaczać wiedzę odkrywaną przez Boga istotom rozumnym ${ }^{30}$. Nie jest wykluczone, iż Orygenes niekiedy w komentarzu utożsamiał z sobą biblijne drzewo życia posadzone w środku ogrodu Eden $\mathrm{z}$ drzewem wiadomości dobra i zła ${ }^{31}$. Drzewo poznania jest równoznaczne z prawem Bożym, które daje życie podobnie jak prawo grzechu jest dla niego jednoznaczne z prawem śmierci. Drzewo wiadomości dobra i zła ma więc swoje odniesienie do Chrystusa, który daje życie i wyzwala spod prawa śmierci ${ }^{32}$. Gdyby człowiek w raju był wierny Bożemu prawu byłby nieśmiertelny ${ }^{33}$, skoro zaś przez nieposłuszeństwo utracił swoją doskonałość potrzebował Zbawiciela, by go wybawił. Drzewo znajomości dobra i zła zostało przez Adamantiosa powiązane z tajemnicą odkupienia, Chrystus zaś jako „ostatni Adam” przez własne posłuszeństwo dał

26 Por. Clemens Alex., Stromata III, 17, 104, PG 8, 1205-1208.

27 Por. Origenes, De principiis IV, 3, 1, SCh 268, 343-347, ŹMT 1, 354.

28 Por. tenże, Contra Celsum IV, 39, SCh 136, 282-288, tłum. S. Kalinkowski, Przeciw Celsusowi, Warszawa 1986, s. 209-210.

29 Por. tenże, De principiis IV, 3, 1, SCh 268, 343-347, ŹMT 1, 354.

30 Por. tenże, Homiliae in Jesu Nave 13, 4, SCh 71, 310-312, PSP 34/2, 75.

31 Por. tenże, Philocalia I, 17, SCh 302, 182-198, tłum. K. Augustyniak, Filokalia, Warszawa 1979, s. 17.

32 Por. tenże, Commentarium in Epistulam Romanos VI, 11, PG 14, 999-1001, PSP 57, 341 .

33 Por. tenże, Commentarii in Evangelium Ioannis XIII, 34, 223-224, SCh 222, 150, ŹMT 27, 319-320. 
się na nim ukrzyżować, by zło przybite do niego zginęło, a dobro odzyskało życie dzięki mocy ${ }^{34}$.

Pod niewątpliwym wpływem Orygenesa i jego biblijno-teologicznej koncepcji egzegezy duchowej nauczał Grzegorz z Nyssy (+394), jeden z najwybitniejszych teologów Kapadockich. W prologu Homilii do Księgi Pieśni nad Pieśniami, czerpiąc inspirację od Adamantiosa, podał metodologiczne zasady komentarza. Zauważył, że w tekście natchnionym oprócz sensu literalno-historycznego, który jest niewystarczający, można odnaleźć znaczenie anagogiczne, tropologiczne, czy też alegoryczne - ogólnie określane przez niego jako duchowe. Jako przykład odwołał się do Księgi Rodzaju i znaczenia drzewa, z którego Bóg zakazał jeść owoców pierwszym rodzicom ${ }^{35}$. Nysseńczyk uważał, iż określenie to zawiera ukrytą treść duchową, którą można z Bożą pomocą odnaleźć. Według niego nie chodzi tutaj o figowiec, jak niektórzy uważali, ani o jakieś inne konkretne drzewo owocowe. Gdyby bowiem ich owoce były trujące, to i dzisiaj nie nadawałyby się do jedzenia. Byłoby to również sprzeczne $\mathrm{z}$ rozporządzeniem Stwórcy, który wszystko stworzył dobre oraz polecił człowiekowi, z jedynym zastrzeżeniem dotyczącym drzewa poznania, do woli korzystać $\mathrm{z}$ owoców drzew rosnących w raju. Zatem Grzegorz szukał głębi nauki o drzewie wiadomości w znaczeniu alegorycznym i bezpośrednio powiązał ją z wyjaśnieniem znaczenia rosnącego w środku ogrodu drzewa życia. Jako punkt wyjścia swoich rozważań postawił pytanie: jak to możliwe, że w środku raju znalazły się obok siebie dwa drzewa, drzewo zbawienia i drzewo zguby ${ }^{36}$ ? W ścisłym znaczeniu środek znajduje się w jednym punkcie. Nie może być dwóch miejsc centralnych, a w tym wypadku dwóch drzew. Jeśli Biblia mówi o oddzielnie rosnących obok siebie drzewach, to jak to możliwe, by oba stały w środku ogrodu? Wątpliwość budzi również samo istnienie drzewa zguby. Drzewo śmiercionośne nie mogło być przecież zasadzone przez Boga, który, jak podają pierwsze wersety Księgi Genesis, wszystko, co stworzył, uczynił dobrym. Grzegorz, by wyjaśnić te rodzące się wśród chrześcijan wątpliwości, odwołał się do filozofii i znaczenia duchowego. Dowodził, iż w rzeczywistości w środku ogrodu było jedynie drzewo, które daje życie. Drzewo, którego owocem jest śmierć, nie ma swego miejsca samo z siebie, nie zostało bowiem zasadzone i ukorzenione. Śmierć rodzi się tam, gdzie umiera życie, a dokonuje się to przez zmieszanie przeciwieństw ${ }^{37}$. Rajskie drzewo poznania dobra i zła symbolizuje naturę grzechu, który niesie

34 Por. tenże, Homiliae in Jesu Nave 8, 6, SCh 71, 230-234, PSP 34/2, 75.

35 Por. Gregorii Nysseni, Homiliae in Canticum canticorum, Prolog 10-11, PG 44, 755-758, ŹMT 43, 20-21.

36 Por. tamże.

37 Por. tamże, XII, 350, PG 44, 1019-1024, ŹMT 43, 183. 
w sobie piękno owocu - przyjemność, subiektywne dobro oraz ukrytą pod tą powłoką szpetotę zła. Nysseńczyk mówi o tym w sposób następujący:

Dlatego Pismo stwierdziło, że oba drzewa znajdują się pośrodku: jedno ze swej natury, a drugie pojawiło się, gdy zabrakło [dobra], bowiem z tego samego drzewa poprzez uczestnictwo lub brak dokonuje się w tym samym czasie zamiana życia i śmierci, ilekroć ktoś, umierając dla dobra, zaczyna żyć w złu, a ktoś inny, uśmiercony dla zła, powraca do życia w cnocie ${ }^{38}$.

Podobną myśl odnajdujemy w Grzegorzowym traktacie De hominis opificio, gdzie między innymi rozważając problematykę życia w raju podjął temat drzewa zakazanego i jego owoców. Według niego Pismo św. termin $\gamma v \tilde{\omega} \sigma \iota \varsigma$ w wyra-

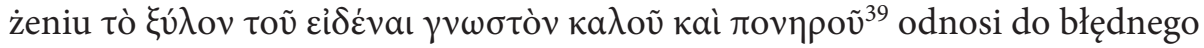
osądu człowieka, który pragnienie swoje ukierunkowuje ku złu, stanowiącemu jedynie pozór dobra. Dlatego właśnie Bóg zakazał pierwszym rodzicom sięgać po owoce tego drzewa. Owocem bowiem drzewa gnozy jest zmieszanie w sobie przeciwieństw. Drzewo poznania rodzi bowiem owoce, które nie są samym złem, wydają się dobre i w osądzie niewiasty budzą rozkosz dla oczu, ani czystym dobrem, gdyż ukrywają w sobie truciznę. Zatem drzewo to pokazuje złożoną naturę zła, które ukazuje się jako pozór dobra, a w rzeczywistości niesie w sobie, ukrytą podstępnie śmierć i zagładę ${ }^{40}$. Podobnie jak prawdziwe dobro jest ze swej natury proste i nie ma styczności ze złem, tak natura zła niesie w sobie złożoność i różnorodność, która pod pozorem dobra omamia zmysły i po skosztowaniu jej zabija swym jadem ${ }^{41}$.

Problematyka właściwej interpretacji dotyczącej biblijnego przekazu o rajskim drzewie poznania dobra i zła pojawiła się również w nauczaniu wybitnego antiocheńskiego kaznodziei - Jana Chryzostom (+407). Około 386 r., wkrótce po przyjęciu święceń prezbiteratu, wygłosił on cykl homilii opartych na egzegezie Księgi Rodzaju i dwie z nich poświęcił bezpośrednio tematyce związanej $\mathrm{z}$ drzewem wiadomości ${ }^{42}$. Za punkt wyjścia swego komentarza $\mathrm{w}$ tej kwestii uczynił pytania: czy od zerwania owocu z tego drzewa pochodzi zdolność Adama do rozeznawania czym jest dobro, a czym zło, czy też posiadał on tę umie-

38 Tamże, XII, 351-352, PG 44, 1021-1022, ŹMT 43, 184.

$39 \mathrm{Rdz} 2,8$.

40 Por. W. Szczerba, A Bóg będzie wszystkim we wszystkim... Apokatastaza Grzegorza $z$ Nyssy, Kraków 2008, s. 262-263.

41 Por. Gregorii Nysseni, De hominis opificio XX, PG 44, 197-202, ŹMT 39, 106-108.

42 Por. S. Kaczmarek, Egzegeza biblijna w Homiliach na Księge Rodzaju (Rdz 1-3) św. Jana Chryzostoma, w: Jan Chryzostom, Homilie na Księgę Rodzaju, Kraków 2008, s. 10. 
jętność przed popełnieniem grzechu? ${ }^{43}$ Gdyby bowiem dopiero od momentu spożycia owocu z zakazanego mu przez Boga drzewa otrzymał wiedzę o tym co jest dobre, a co złe, znaczyłoby to, iż to grzech nieposłuszeństwa stał się dla niego źródłem poznania i „nauczycielem mądrości”. W tym kontekście szatan, który pod postacią węża skłonił człowieka do zerwania owocu z tego drzewa niebyły zwodzicielem, lecz „pożytecznym doradcą”, gdyż dzięki jego wskazaniom Adam z bytu nierozumnego, podobnego zwierzętom, stałby się istotą rozumną - człowiekiem ${ }^{44}$. Przytoczona przez Chryzostoma powyższa argumentacja zdaje się korespondować z kontrowersyjnymi poglądami głoszonymi w tej kwestii przez gnostyków ${ }^{45}$. Antiocheńczyk, odrzucając zdecydowanie taki punkt widzenia przytacza biblijne dowody na to, iż człowiek od początku stworzenia był istotą rozumną, gdyż jedynie istoty z natury pozbawione rozumu nie wiedzą co jest dobre, a co złe. Według niego, człowiek uczyniony na obraz i podobieństwo Boże, nie mógł być pozbawiony przez Boga tak wielkiego daru. Na dowód wielkiej mądrości Adama i w odróżnieniu od istot bezrozumnych, które nie posiadają umiejętności oceniania czym jest nieprawość, a czym cnota, podał przykład nadania przez pierwszego człowieka imion wszystkim zwierzętom oraz rozpoznania w Ewie uczestniczki swej natury ${ }^{46}$. W związku z tym postawił kolejne pytanie: skoro człowiek nie otrzymał poznania $\mathrm{z}$ drzewa, dlaczego nosi ono w Biblii nazwę „poznania dobra i zła”? Przecież nie dlatego, dowodzi Złotousty, iż szatan powiedział, iż gdy zjedzą owoc z tego drzewa, to otworzą się im oczy i będą jak bogowie, znając dobro i zło? Człowiek po grzechu bowiem nie tylko nie stał się bogiem, ale też nie uzyskał poznania. Zresztą nie jest tutaj argumentem świadectwo diabła. By zrozumieć tę kwestię, trzeba poznać, czym według Pisma św. jest dobro, a czym zło. Dobrem jest posłuszeństwo, złem zaś nieposłuszeństwo. Zatem według Jana Chryzostoma dlatego temu rajskiemu drzewu nadano nazwę „poznania dobra i zła”, gdyż właśnie przy nim Bóg nadał człowiekowi przykazanie sprawdzające jego znajomość dobra i zła oraz dokonał się obok niego akt wykazania się przez ludzi wiernością swemu Stwórcy ${ }^{47}$. Adam wiedział, że dobrem jest uległość względem Boga, a samowola złem, jednak dopiero wtedy w pełni to zrozumiał, kiedy za nieposłuszeństwo spadła na

43 Por. Joannis Chrysostomi, Homiliae in Genesim VI, 1, SCh 433, 280-311, ŹMT 45, 92-93.

44 Por. tamże, VI, 2, SCh 433, 311-319, ŹMT 45, 94-95.

45 Podobne poglądy pojawiały się wśród gnostyckich ugrupowaniach setian, kainitów i ofitów.

46 Por. Joannis Chrysostomi, Homiliae in Genesim VI, 1-2, SCh 433, 280-284, ŹMT 45, 92-95.

47 Por. tamże, VII, 3, SCh 433, 318-327, ŹMT 45, 101. 
niego kara wygnania z raju i pozbawienia szczęśliwości. Złotousty porównuje tę sytuację do zdrowego człowieka, który wie, czym jest choroba, jednak gdy jej sam doświadczy i cierpi, lepiej poznaje różnicę. Dowodząc, iż nazwa drzewa „poznania dobra i zła” jest jedynie biblijną konwencją nadawania miejscom i czasom określeń związanych ze zdarzeniami, które się przy nich dokonały przywołał kilka przykładów, gdzie np. studnia wykopana przez Izaaka otrzymała nazwę „Nienawiść” (Rdz 26, 21), ze względu na to, że przy niej narodziła się wrogość sąsiadów do Izaaka, lub „Studnia przysięgi” (Rdz 21, 31-32), gdyż przy niej Abraham z Abimelekiem złożyli swoją przysięgę ${ }^{48}$. Zatem to nie natura drzewa ma w sobie poznanie dobra i zła, ale przy nim człowiek wykazał się przed Bogiem wiernością jego przykazaniu.

W podobnym duchu omówił znaczenie rajskiego drzewa dobra i zła wielki teolog Zachodu - św. Augustyn z Hippony $(+430)$. Nie był on najwybitniejszym egzegetą, a problemy związane $\mathrm{z}$ dogłębnym komentarzem biblijnym podejmował głównie z przyczyn pastoralnych bądź polemicznych ${ }^{49}$. Tak było i tym razem, gdy podjął dyskusję ze znanymi mu przecież bardzo dobrze poglądami manichejczyków ${ }^{50}$. Augustyn w duchu istniejącej już w tej materii tradycyjnej nauki Kościoła mówi, iż drzewo poznania znajdujące się w rajskim ogrodzie nie mogło być ze swej natury złe, a jego owoce szkodliwe dla człowieka i niosące same w sobie śmierć, gdyż było ono zasadzone przez Boga. Stwórca, który wszystko uczynił dobre, nie posadził w Edenie drzewa, które mogło być złe. Pewnym novum w interpretacji Augustyna jest fakt, iż uważał on za faktyczne istnienie w zamierzchłej historii tego konkretnego drzewa. Tłumaczył to występującą na kartkach Pisma św. koncepcją tzw. realizmu symbolicznego. Otóż Biskup Hippony zakładał, iż fundamentalnym kryterium metodologicznym szczególnie w interpretacji pierwszych rozdziałów Księgi Genesis jest odnalezienie głębi znaczenia alegorycznego - duchowego, które jest zawsze, rozpoczęte od wyjaśnienia znaczenia historycznego, które również może być ważne dla właściwego odczytania wartości doktrynalnej tekstu ${ }^{51}$. Mając to na uwadze, stwierdził, iż w Biblii jest wiele dowodów na łączenie treści literalnej, o faktycznych wydarzeniach, czasach i osobach, z później odczytanym w niej znaczeniem metaforycznym. Jako przykład przywołał obraz wiecznego niebie-

48 Por. tamże, VII, 2-3, SCh 433, 311-327, ŹMT 45, 99-101.

49 Por. W. Myszor, Wstęp, w: św. Augustyn, Pisma egzegetyczne przeciw manichejczykom, Warszawa 1980, s. 5-7.

50 Por. Augustinus, De Genesis contra Manichaeos libri duo II, 25, 38, PL 34, 216-217, PSP 25, 77.

51 Por. M. Simonetti, Między dosłownościa a alegoria, tłum. T. Skibiński, Kraków 2000, s. $347-357$. 
skiego Jeruzalem oraz Jerozolimy - miasta istniejącego historycznie w Palestynie, jak też Sarę i Hagar, które według Listu do Galatów (4, 24-26) oznaczają dwa przymierza, to jednak były to kobiety, żyjące w określonych ramach historycznych $^{52}$. Podobnie i opisane w Księdze Rodzaju drzewo istniało rzeczywiście, jako materialne i podobne do innych drzew. Do niego została przypisana nazwa „poznania dobra i zła”, nie ze względu na jego owoce, czy też szczególną naturę, lecz z powodu rozegranego przy jego udziale tragicznym w swe skutki dramacie grzechu. Zło nie tkwiło w drzewie czy też w jego owocu, lecz w przekroczeniu przez człowieka przykazania Boga. Stwórca zakazując pierwszym rodzicom dotykania tego drzewa odkrył przed nimi siebie, jak Pana wszelkiego stworzenia i źródło dobra, ku któremu winien być ukierunkowany człowiek ${ }^{53}$. Ludzie jednak przez nieposłuszeństwo odwrócili się od tego, co było dla nich najlepsze i zwracając się ku stworzeniu naruszyli zbawienną dla nich harmonię oraz szczęście. Drzewo poznania otrzymało więc nazwę od skutku zakazanego dotknięcia, kiedy to człowiek odczuł namacalnie na swojej historii różnicę miedzy wiernością Bogu a nieposłuszeństwem ${ }^{54}$. Określone przez Augustyna kryterium metodologiczne pozwalało ten sam tekst biblijny interpretować w innym kontekście alegorycznym. Dlatego też w kolejnym miejscu znaczenie drzewa poznania dobra i zła odniósł do wnętrza duszy, jednakże konsekwentnie zachował te same przesłanie teologiczne. Dusza mianowicie winna być zawsze ukierunkowana ku Bogu, którego prawa i moc utrzymują porządek natury. Gdy zechce używać własnej swej władzy bez Boga, porzucając jego prawa i skłaniając się ku rozkoszom stworzenia, wtedy doświadczy, jaka jest różnica między dobrem, które utraciła, a złem, w którego niewolę się oddała. Takie jest według Biskupa Hippony znaczenie biblijnego opisu skosztowania owocu drzewa dobra i zła.

Podsumowując niniejsze opracowanie możemy stwierdzić, iż problematyka związana ze zrozumieniem znaczenia rajskiego drzewa poznania dobra i zła należała w czasach patrystycznych do tematów ważnych i szeroko komentowanych. Było to uwarunkowane $\mathrm{z}$ jednej strony koniecznością przeciwstawienia się kontrowersyjnym, z punktu widzenia Kościoła, heretyckim interpretacjom, z drugiej zaś potrzebą pozytywnego omówienia i sformułowania chrześcijańskich dogmatów opartych ma nauce Biblii. Rajska historia tragedii związanej $\mathrm{z}$ sięgnięciem przez pierwszych rodziców po zakazany owoc z drzewa pozna-

52 Por. Augustinus, De Genesis ad litteram libri duodecym VIII, 4, 8, PL 34, 375-376, PSP 25, 256-257.

53 Por. tenże, De natura boni 34, CPL 323, tłum. M. Maykowska, O naturze dobra, w: św. Augustyn, Dialogi filozoficzne, Kraków 1999, s. 847.

54 Por. tenże, De Genesis ad litteram libri duodecim VIII, 6, 12, PL 34, 377, PSP 25, 259. 
nia stała się fundamentem do teologicznego ujaśnienia nauki o naturze Boga, o stworzeniu, grzechu pierworodnym, odkupieniu itd. Analiza wybranych źródeł wczesnochrześcijańskich pozwala stwierdzić, iż mimo bogactwa interpretacji kwestii szczegółowych (głównie alegorycznej) dotyczących drzewa wiadomości (gatunku, rodzajów owoców, miejsca zasadzenia itd.), daje się wyodrębnić w tradycyjnej nauce Kościoła pewne prawidłowości. Jedną z zasadniczych jest mocno podkreślana przez pisarzy wczesnochrześcijańskich prawda o Bogu, który wszystko stworzył dobre. Zatem rajskie drzewo poznania dobra i zła, jak też jego owoce były z natury dobre. Drzewo to było symbolem porządku ustanowionego przez Stwórcę, a grzech człowieka, związany z sięgnięciem po jego owoce, nieposłuszeństwem. Wraz z upływem kolejnych wieków w teologii Kościoła rajska opowieść o drzewie poznania i niewierności człowieka była coraz częściej interpretowana w nawiązaniu do całości historii zbawienia, w szczególności zaś do Chrystusowego posłuszeństwa i drzewa krzyża, na którym dokonało się zbawienie świata.

\section{Summary}

The biblical story of Adam and Eve as well as their breaking the fruit from the tree of knowledge of good and evil are one of the most intriguing ones in the history of theology. Throughout the centuries both Christians and heretics have been trying to find the answer for the most fundamental question concerning man and his creation, the sense of existence, vocation, the tendency to do good or evil, cosmology, etc. This chapter aims at describing a study over the tree of knowledge of good and evil on the basis of some particular early Christian writers. The Christian Church was once predominated with the idea that everything created by God was in its nature good. Thus the heavenly tree of knowledge with all its fruit were good in nature. The tree in the Christian Church tradition has become the symbol of order as established by the Creator, while the fact of a human reaching for the fruit stands for his disobedience and sin. This science has significantly influenced the articulation of dogma on God's nature, creation, original sin, salvation and many more. 